\title{
A Rare Cause for Hematuria: Lymphoma of the Urinary Bladder
}

\begin{abstract}
Primary lymphomas of the urinary bladder are rare and majority present with hematuria. Patients are usually elderly females with a history of recurrent cystitis. The diagnosis is clinched after imaging and biopsy of suspicious lesions in the bladder. The prognosis is good irrespective of the modality of treatment. With this background, we report a case of primary marginal zone lymphoma of the urinary bladder (Stage $I_{E}$ ) in a young lady with no history of cystitis, who presented with isolated hematuria. After treatment with radiotherapy alone, patient is in complete remission for the past 18 months. The timely diagnosis in a patient with hematuria holds the key to successful treatment and its importance cannot be overemphasized.
\end{abstract}

Keywords: Hematuria, marginal zone lymphoma, mucosa-associated lymphoid tissue, primary lymphoma, radiotherapy, urinary bladder

\section{Introduction}

Primary lymphomas of the urinary bladder are rare, representing $0.2 \%$ of all known bladder cancers. ${ }^{[1]}$ The most common symptoms of bladder lymphomas are macroscopic hematuria, dysuria, and increased frequency of micturition. ${ }^{[2]}$ In the literature reported so far, patients are usually elderly and have a history of chronic cystitis. Herein, we report a case of a young female with no such history, who is in complete remission after treatment.

\section{Case Report}

A 35-year-old lady with no comorbidity presented to the urologist with 1-month history of painless hematuria. On physical examination, no pallor, lymphadenopathy, hepatosplenomegaly, or any mass in the pelvis was detected. The urine routine and microscopic examination was confirmative of hematuria. Thereafter, a contrast-enhanced computed tomography (CECT) of the abdomen and pelvis showed a large, lobulated mass, $96 \mathrm{~mm} \times 46 \mathrm{~mm} \times 63 \mathrm{~mm}$, in the posterolateral wall of the urinary bladder with few subcentimeters internal iliac and left obturator lymph nodes. The mass was encasing the left vesicoureteral junction causing mild proximal hydroureteronephrosis [Figures 1 and 2].

This is an open access journal, and articles are distributed under the terms of the Creative Commons Attribution-NonCommercial-ShareAlike 4.0 License, which allows others to remix, tweak, and build upon the work non-commercially, as long as appropriate credit is given and the new creations are licensed under the identical terms.

For reprints contact: WKHLRPMedknow_reprints@wolterskluwer.com
Subsequently, cystoscopy showed a well-defined, lobulated submucosal mass arising from the posterior wall from which biopsy was taken. Histopathological examination of the biopsy specimen revealed infiltration of the bladder mucosa by sheets of monomorphic population of small, atypical lymphocytes, suggestive of non-Hodgkin's lymphoma [Figure 3].

The immunohistochemistry was positive for leucocyte common antigen and also for CD20, [Figure 4] Bcl2, CD5, CD43, CD68, and MPO. About $40 \%$ of cells stained positive for MIB-1 [Figure 5]. CD10 and cyclin D1 were negative, consistent with marginal zone B-cell lymphoma (MZL) with a high proliferative index.

The patient had a hemoglobin of $11.5 \mathrm{~g} / \mathrm{dl}$ and total leukocyte count of $5500 / \mathrm{mm}^{3}$ with $78 \%$ neutrophils and platelet count of 3.5 lakhs $/ \mathrm{mm}^{3}$. Her lactate dehydrogenase was $139 \mathrm{U} / \mathrm{L}$. Bone marrow aspiration and trephine bone biopsy did not show infiltration by lymphoma and CECT of the neck and thorax showed no disease elsewhere. Hence, the final diagnosis of primary MZL of the urinary bladder stage $\mathrm{I}_{\mathrm{E}}$ was confirmed.

In view of localized disease, the patient was treated with curative intent, by means of radiation therapy of $50 \mathrm{~Gy}$ in 25 fractions. She tolerated the therapy well with no major side effects following which the hematuria subsided. A repeat CECT of

How to cite this article: Mathew SP, Parikh S, Anand A, Srivastava V. A rare cause for hematuria: Lymphoma of the urinary bladder. Indian J Med Paediatr Oncol 2020;41:764-6.
Sherin P Mathew, Sonia Parikh, Asha Anand, Vaibhava Srivastava

Department of Medical Oncology, Gujarat Cancer and Research Institiute, Ahmedabad, Gujarat, India

Submitted: 03-Nov-2019

Revised: 21-Feb-2020

Accepted: 15-Mar-2020

Published: 29-Oct-2020

Address for correspondence: Dr. Sherin P Mathew, Department of Medical Oncology, Gujarat Cancer and Research Institiute, Ahmedabad, Gujarat, India. E-mail: sherin.p.mat@gmail. com

Access this article online

Website: www.ijmpo.org

DOI: 10.4103/ijmpo.ijmpo_224_19 Quick Response Code:

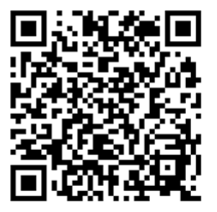




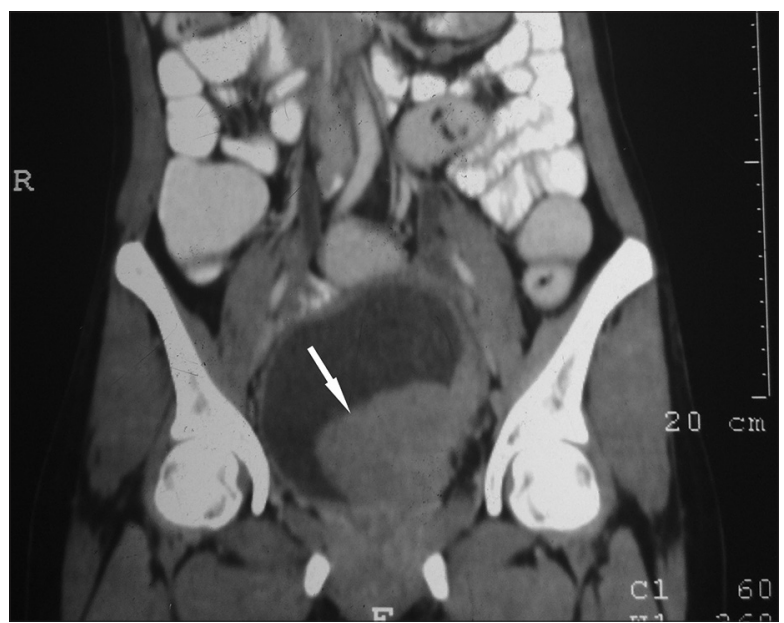

Figure 1: Contrast enhanced computed tomography of the abdomen and pelvis showing the tumor arising from the posterolateral bladder wall - Coronal section

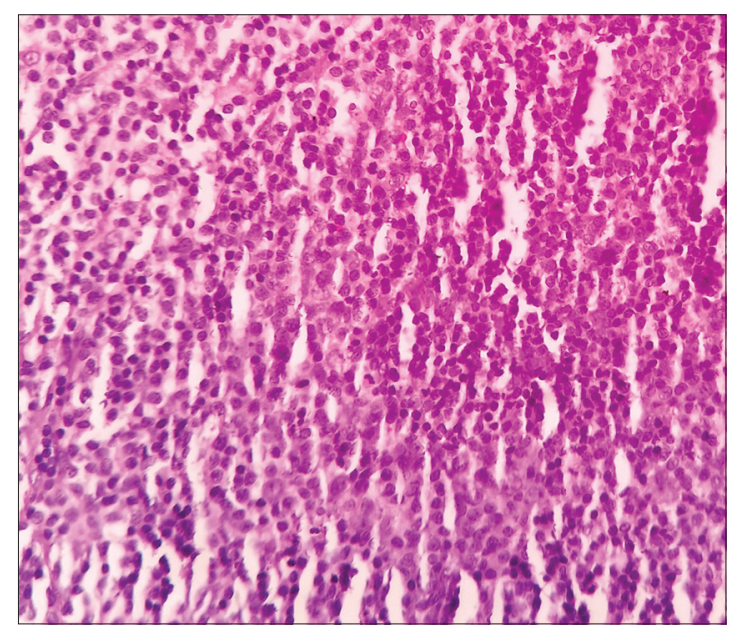

Figure 3: Atypical lymphocytes infiltrating the submucosa of the urinary bladder ( $\mathrm{H}$ and $\mathrm{E}, \times \mathbf{4 0})$

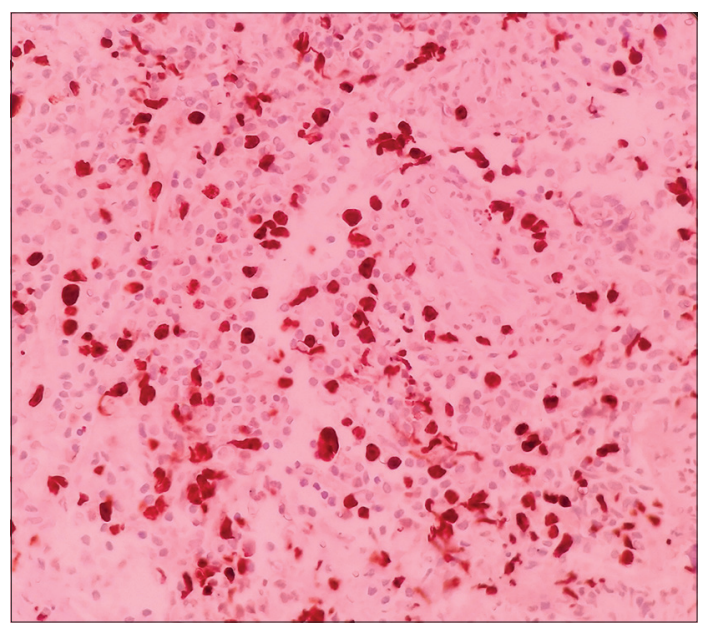

Figure 5: MIB-1 positivity among $40 \%$ of tumor cells $(\times 40)$

the pelvis showed soft-tissue density lesion with a size of $21 \mathrm{~mm} \times 37 \mathrm{~mm} \times 32 \mathrm{~mm}$ at the base of the urinary bladder - presumably residual disease or postradiation changes.

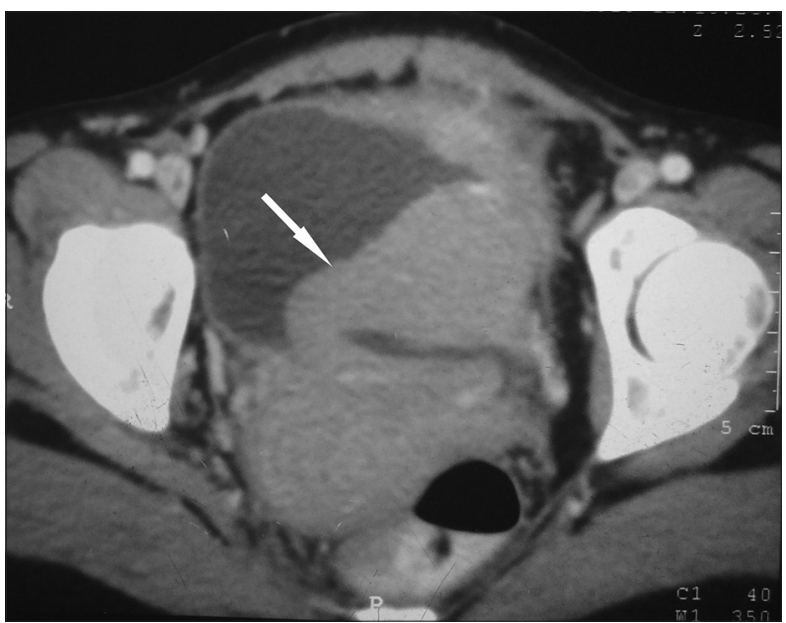

Figure 2: Axial section of the same contrast enhanced computed tomography showing the tumor

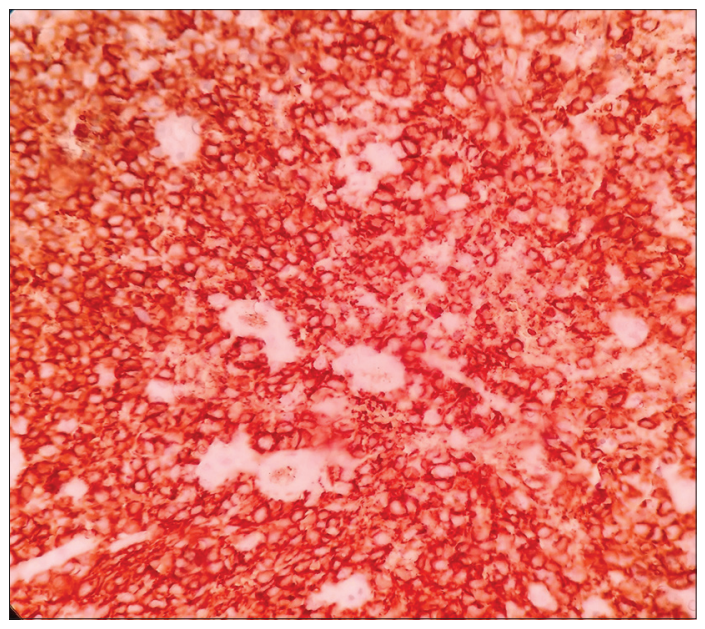

Figure 4: The tumor cells staining for CD20 on immunohistochemistry $(\times 40)$

After 2 months, it had reduced to a size of $17 \mathrm{~mm} \times 35 \mathrm{~mm}$, and cystoscopic guided biopsy was negative for malignancy. She is under observation with CECT pelvis and urine cytology now. Her recurrence-free survival is 18 months.

\section{Discussion}

Since the first report of primary lymphosarcoma of the urinary bladder by Eve in $1885,{ }^{[2]}$ much has come to light about this rare lymphoma. It was classified along with sarcomas and the treatment has evolved from surgery alone to adjuvant radiotherapy and then to multimodality therapy.

Extranodal marginal zone lymphomas or mucosa-associated lymphoid tissue (MALT) lymphomas were first described by Isaacson in 1983 where he postulated the MALT concept to explain the development of lymphomas in organs with no lymphoid tissues ${ }^{[1]}$ This concept of acquisition of lymphoid tissue due to chronic antigenic stimulation by a bacterial infection is supported by the history of chronic cystitis, seen in around $20 \%-40 \%$ of the cases. ${ }^{[3]}$ On the other hand, in those cases with no such previous history, like ours, the 


\begin{tabular}{|c|c|c|c|c|}
\hline Author & Age (years)/gender & Presenting symptoms & Treatment & Outcome \\
\hline 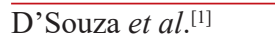 & $56 /$ male & Hematuria, clot retention & TURBT & $\mathrm{CR}$ at 3 years \\
\hline Combaz and $\mathrm{Kuhn}^{[2]}$ & 67/female & Recurrent cystitis, asthenia & Rituximab (375 mg/m² weekly, 4 weeks) & $\mathrm{CR}$ at 3 years \\
\hline Isono et al., $2018^{[3]}$ & 77/female & Frequency, hematuria, cystitis & Radiotherapy (30.6 Gy in 17 fractions) & $\mathrm{CR}$ at 5 years \\
\hline Ozawa et al..$^{[5]}$ & 72/female & Thrombocytosis & TURBT & $\mathrm{CR}$ at 13 months \\
\hline Matsuda et al. ${ }^{[7]}$ & 78/female & $\begin{array}{l}\text { Refractory cystitis and renal } \\
\text { dysfunction }\end{array}$ & Rituximab $\times 4$ cycles & PR \\
\hline $\begin{array}{l}\text { Haddad-Lacle et al., } \\
2014^{[8]}\end{array}$ & 54/male & Low back pain & Radiotherapy (30.6 Gy in 17 fractions) & $\begin{array}{l}\text { No recurrence at } \\
3 \text { years }\end{array}$ \\
\hline Chen et al..$^{[9]}$ & $63 /$ female & $\begin{array}{l}\text { Gross hematuria and urethral } \\
\text { caruncle }\end{array}$ & $\begin{array}{l}\text { Radiotherapy to bladder ( } 36 \mathrm{~Gy} \text { ) and } \\
\text { pelvic and inguinal lymph nodes ( } 45 \mathrm{~Gy} \text { ) }\end{array}$ & $\begin{array}{l}\text { Uneventful at } 11 \\
\text { months }\end{array}$ \\
\hline Hsu et al., 2015[10] & 76/female & Recurrent cystitis & Radiotherapy & $\mathrm{CR}$ at 3 months \\
\hline
\end{tabular}

CR - Complete remission; PR - Partial response; TURBT - Transurethral resection of bladder tumor

alternative hypothesis is the development of tumors from the lymphoid tissue derived from the embryonic cloaca. ${ }^{[2]}$

Extranodal marginal zone lymphomas are most common among primary urinary bladder lymphomas. More than 50 cases of primary bladder marginal zone lymphomas have been reported so far, after the first by Kuhara et al. in $1990 .{ }^{[4]}$ Patients are mostly elderly females, more than 60 years of age, with a history of chronic cystitis in the past, contrary to the patient reported here. Hematuria was the predominant symptom in $60 \%$, with others having dysuria and urinary frequency. ${ }^{[2]}$

Since there is no consensus on the optimal therapy, either of radiation, chemotherapy, targeted therapy, or a combination have been attempted and are successful in attaining remission. A few patients were treated with local therapy only, such as transurethral resection of bladder tumor ${ }^{[5]}$ and diathermy. There was one patient who attained CR with Helicobacter pylori eradication therapy alone, ${ }^{[6]}$ while another patient was treated exclusively with rituximab. ${ }^{[2]}$ In this context, all cases reported after 2014 are shown in Table 1 . The prognosis remains good despite the modality of treatment used, but rarely, it can disseminate or transform into higher grade diffuse large B-cell lymphoma. ${ }^{[2,7]}$

\section{Conclusion}

Although marginal zone lymphoma of the bladder is not a common diagnosis of a patient with hematuria, hematuria is its most common presentation. Hence, urine cytology and cystoscopy should be done in persistent cases of hematuria to rule out the same, as it has a very good prognosis with any form of either local or systemic therapy.

\section{Declaration of patient consent}

The authors certify that they have obtained all appropriate patient consent forms. In the form the patient(s) has/have given his/her/their consent for his/her/their images and other clinical information to be reported in the journal. The patients understand that their names and initials will not be published and due efforts will be made to conceal their identity, but anonymity cannot be guaranteed.

\section{Acknowledgment}

The authors are grateful to the Department of Pathology, Gujarat Cancer and Research Institute for the photomicrographs.

\section{Financial support and sponsorship}

Nil.

\section{Conflicts of interest}

There are no conflicts of interest.

\section{References}

1. D’Souza N, Verma A, Rai A. Two cases of non-Hodgkin lymphoma of urinary bladder: Primary and secondary. J Cancer Res Ther 2017;13:1053-5.

2. Combaz N, Kuhn A. Case report about a primary bladder lymphoma. Int Arch Urol Complicat 2017;3:1-6.

3. Isono M, Sato A, Kimura F, Asano T. A case of mucosa-associated lymphoid tissue lymphoma of the bladder successfully treated with radiotherapy. Urol Case Rep 2018;16:1-3.

4. Kuhara H, Tamura Z, Suchi T, Hattori R, Kinukawa T. Primary malignant lymphoma of the urinary bladder. A case report. Acta Pathol Jpn 1990;40:764-9.

5. Ozawa M, Suenaga S, Ishii T, Suzuki H, Tsuchiya N, Ohtake H. Primary malignant lymphoma of the bladder diagnosed by transurethral bladder tumor resection: A case report. Nihon Hinyokika Gakkai Zasshi 2018;109:45-9.

6. van den Bosch J, Kropman RF, Blok P, Wijermans PW. Disappearance of a mucosa-associated lymphoid tissue (MALT) lymphoma of the urinary bladder after treatment for Helicobacter pylori. Eur J Haematol 2002;68:187-8.

7. Matsuda I, Zozumi M, Tsuchida YA, Kimura N, Liu NN, Fujimori Y, et al. Primary extranodal marginal zone lymphoma of mucosa-associated lymphoid tissue type with malakoplakia in the urinary bladder: A case report. Int J Clin Exp Pathol 2014;7:5280-4.

8. Haddad-Lacle JE, Haddad CJ, Villas B. A rare urinary bladder tumour. BMJ Case Rep [Internet]. 2014 May;2014:bcr2013202994:[about 2p.]. Available from: https://casereports.bmj.com/content/2014/bcr2013-202994.long. [Last cited 2019 Oct 17].

9. Chen YR, Hung LY, Chang KC. Mucosa-associated lymphoid tissue-type lymphoma presenting as a urethral caruncle with urinary bladder involvement. Int J Urol 2014;21:1073-4.

10. Hsu JS, Lin CC, Chen YT, Lee YC. Primary mucosa-associated lymphoid tissue lymphoma of the urinary bladder. Kaohsiung $\mathrm{J}$ Med Sci 2015;31:388-9. 